\title{
CAMPAIGN SPENDING AND OFFICE-SEEKING MOTIVATIONS: AN EMPIRICAL ANALYSIS
}

This version: October 5th, 2006

\begin{abstract}
This paper presents econometric evidence on the relationship between campaign spending and office seeking motivations. Our results, using Spanish data, show that campaign spending per capita is higher in the elections where the stakes for the winner, measured by the appointment power of the office, are greater. Moreover we find that campaign expenses per capita increase with the level of self-government of the region. Our results concord with those reported for other countries with very different systems of campaign funding.
\end{abstract}




\section{INTRODUCTION}

An important motivation for people to affiliate with a party is to increase their chances to get a position in government after the election. This is especially true in European systems where closed party lists make it very difficult for an independent candidate to be elected.

At the same time party leaders bear in these systems a strong pressure from their party members because they can only include a small number of them in the party list to the legislature or appoint a few as high level officials if the party wins the election. Therefore, other things equal, it would be in the best interest of both party leaders and members to spend more campaign funds in those jurisdictions where the appointment capacities of the executive are greater.

The relevance of future power as a determinant of campaign expenses has been empirically investigated for the political system of the United States since the late seventies. Several papers - Crain and Tollison (1977), Crain, Deaton and Tollison (1977) and Gifford and Santoni (1978) measured to what extent campaign funds raised by candidates depended on the size of the public budget to be controlled. These studies found a significant and positive coefficient between the public budget as a measure of power and the money raised by candidates. Abrams (1981) extended this line of research considering several proxies for the value of government. Apart from public budgets, he included other variables such as the number of government officials that could be appointed, the power of the candidate to incur public debts and several other indexes of the law making capacities of the office. 
Later on Palda (1992) analyzed to what extent candidates' demand for funds is conditioned by the necessity to pay back their donors. More contributions imply less discretional power after the election because part of the power attained is earmarked to favor donors through beneficial legislation or public expenditure programs. According to his results the greater the public budget, the greater also the contributions received by candidates. In addition in those jurisdictions where balanced budget laws had been passed, candidates raised less campaign funds. From a similar theoretical framework, Lott (2000) offers empirical evidence showing that a plausible explanation for the growth of campaign expenses in the United States in recent years is precisely that public budgets are also increasing 1 . Stratmann (1991) and Bronnars and Lott (1997) present related arguments.

Building on this literature we evaluate if office-seeking motivations affect the amount of campaign expenses in parliamentary systems where campaigns are financed mainly by taxpayers' money. Previous studies focused their attention on the American political system, where campaign contributions by individuals or interest groups play an important role. In this study we use data from regional elections in Spain, where strong party discipline and public funding of political parties are the rule. Data from the Spanish regions seem to be adequate to test the effect of the value of future power on campaign spending due to the different sizes and self-government powers of the regions and their similarity regarding other institutional and sociological factors.

We show that campaign expenditures per capita are higher in those jurisdictions where the appointment power of the winning party is greater. This result is robust to several specifications of the model. We also find that differences in the self-government powers of the Spanish regions affect

\footnotetext{
${ }^{1}$ Ansolabehere et al (2003) show however that as a percentage of GDP the increase of campaign contributions has been very small.
} 
campaign expenses per capita. According to our results, total campaign expenditures per capita increase with the level of autonomy of the region. However we find that, contrary to previous studies for American elections Palda (1992), Lott (2000) -, budget per capita as a measure of the power gained by the candidate or party does not seem to be a determinant of campaign spending in Spain. This is interesting as long as it has often been argued - see for instance Lott (2000) or Stratmann (1992) - that campaign contributions are higher in those jurisdictions where big budgets allow candidates to "sell" more favors to donors. In the case of Spain the strict legal limit on private contributions to campaigns may weaken this "auctioning" of public office to lobbyists and therefore could explain why our estimate of budget per capita is not statistically significant.

The remaining sections of the paper are organized as follows. Section 2 offers some background on the Spanish electoral and political institutions. In Section 3 we present the theoretical hypotheses to be tested. Sections 4 and 5 are devoted to present data and econometric methods. In section 6 the main results are discussed. Finally, section 7 concludes.

\section{BACKGROUND}

The purpose of this section is to summarize the basic features of the Spanish electoral system so that the theoretical hypotheses and the empirical results presented later could be better understood. We will first briefly outline the political organization of Spain to go afterwards into the details of its electoral system and campaign finance rules.

a) Political Organization 
Spain has a system with three levels of government: The central government, the regional governments, called Autonomous Communities (Comunidades Autónomas), and the local ones called Ayuntamientos. The Spanish Constitution of 1978 regulates the law making capacities attributed to each level. The central government has some areas of policy in which it has exclusive law making capacities - e.g., defense or foreign affairs ${ }^{2}$. The Autonomous Communities have exclusive regulating rights in other areas such as the organization of the Autonomous Government ${ }^{3}$. In addition, there are some other areas in which both jurisdictions share powers - e.g., economic policymaking. In these areas the national (central) parliament has the right to regulate the general principles and the regional assemblies can pass their own legislation within the boundaries of the general principles set by the national parliament.

The Constitution thus gives the Autonomous Communities a vast autonomy to regulate many areas of policy. However, to be granted such capacities does not imply the obligation for the Autonomous Communities to assume all the policy powers they are allowed to. They can choose either to assume them or not. Therefore, since the restoration of democratic institutions in the late seventies, different Autonomous Communities have undertaken different powers at different moments in time.

There are seventeen Autonomous Communities in Spain. The political organization of each of them is very similar to the organization of the central government. Each has its own legislative assembly, executive and bureaucracy. The President of the Autonomous Community appoints the members of the government and the high level officials of the regional executive. In addition he can also appoint several other influential positions, like the CEO and the members of the board of directors of the publicly owned companies.

\footnotetext{
2 See Spanish Constitution of 1978, article 149.

${ }^{3}$ See Spanish Constitution of 1978, article 148.
} 
Finally, each Autonomous Community has its own budget, which is prepared by the regional executive and has to be passed by the regional assembly every year. The budget includes estimates of public expenditures and the resources for financing them. The Autonomous Communities have the power to levy certain taxes (e.g., the inheritance tax). They are also granted a share in the taxes raised by the central government, mainly a portion of the income tax. On their share of the income tax the Autonomous Communities can award tax allowances to their taxpayers 4 . In addition, regional governments receive transfers from the central government that depend on the duties undertaken by them.

b) Electoral Laws and campaign financing

Electoral laws are part of the regulating powers shared between the central and the regional governments. The national parliament (Cortes Generales) legislated in 1985 the general principles that guide elections in Spain ${ }^{5}$. Within this framework the Autonomous Communities can dictate their own statutes concerning how to elect the members of their assemblies.

Spain has a system of proportional representation in which parties field a list of candidates for each election. Lists are closed so that voters can only cast ballots for parties ${ }^{6}$. Then, seats in Parliament are allocated to parties according to their votes. Autonomous Communities could de facto choose the system of representation, but so far they all have maintained the d'Hondt rule, which privileges big parties.

\footnotetext{
${ }^{4}$ They can create tax credits to different groups of taxpayers. Therefore the income tax differs from region to region.

${ }^{5}$ Ley Orgánica 5/1985 de Régimen Electoral General (General Electoral Law).

6 This system strengthens discipline in party members and the role of party leaders since they decide the place of candidates in party lists.
} 
Each Autonomous Community can determine the number of seats in the regional parliament, the size of the electoral districts, the way seats are allocated and the procedure to choose the regional president.

Campaigns are funded mainly by public budgets while private contributions are subject to a strict limit of 6000 euros per individual or corporation in each election. The limit was established in 1985 by the General Electoral Law and has not been changed since then ${ }^{7}$. As a consequence, donations represent a small part of the campaign spending of Spanish parties. Around 85 per cent of total campaign spending is nowadays publicly funded. This percentage varies from one region to another. For example while in Navarra in the 1999 election almost $98 \%$ of the campaign bill was paid for with public money, in Catalonia that same year, the percentage was $66 \%^{8}$.

Public funding consists on a subsidy to each party that depends on the number of votes and seats that the party obtains in the election. In regional elections the Autonomous Legislatures can decide the amount of public funds per vote, per seat and whether to subsidize other expenses (such as the mailing costs). Different regions have set different amounts for campaign funding. The Autonomous Legislatures can also place limits on the total amount that parties can spend in each district where they field candidates. Legal ceilings on

\footnotetext{
${ }^{7}$ The limit is the same for all regions as long as was established by the General Electoral Law. Unlike the ceiling on campaign spending, the limit to private contributions is not indexed to inflation and therefore is even more restrictive in real terms (2730 euros at 2003 prices).

${ }^{8}$ Data on campaign spending and subsidies in regional elections are taken from the reports of the national and regional Court of Accounts (Informes de Fiscalización sobre las Contabilidades Electorales de las Elecciones Autonómicas). The proportion covered by public funds rose from an average of around $50 \%$ in the eighties to the actual $85 \%$. This was due to the statutory changes in the nineties which lowered the ceiling on campaign spending and increased the public subsidy per vote to limit the dependence of parties from bank loans. Artés Caselles and García Viñuela $(2005,2006)$ provide data and more details on the motivations and the effects of the changes in the campaign finance laws.
} 
campaign spending were set also at very different levels ${ }^{9}$. They are enforced either by the national Court of Accounts, the agency responsible for auditing parties' bookkeeping, or by its regional counterparts when they exist.

According to the law, spending over the legal limit would result in a reduction of the public subsidy received by a party. The limits however were set too high and so far have not been binding. This is especially true for medium or small parties that are subject to the same limits that big parties but spend much less. In addition, mailing costs are not used to compute the limit and therefore parties have plenty of room to spend around the limit in case they found it convenient. The limits were established by the regional electoral laws that need a high degree of consensus to be passed. The incumbent party could only vary them at will in case of enjoying a wide majority of more than $60 \%$ of the seats. But parties enjoying such a majority have never used it to change the limit, partly because of the tradition in Spanish politics of passing electoral laws by consensus ${ }^{10}$.

Although campaigns are publicly financed this does not mean that they are costless for parties. The amount of campaign expenses that a party is reimbursed depends on the votes and seats won in the election. Since parties receive the reimbursement months after the election has taken place they have to make a careful evaluation of their expected electoral results and to resort to

\footnotetext{
${ }^{9}$ All regions have adopted ceilings on campaign spending, but they differ widely. For example in the 2003 regional elections, the ceiling on spending per inhabitant was set for each party at 0,47€ in Extremadura $(1,073,904$ inhabitants in 2003) and La Rioja (287,390 inhabitants), 0.34€ in Catalonia (6,704,146 inhabitants), Murcia (1,269,230 inhabitants) and Castilla-León (2,487,646 inhabitants) and 0.23€ in Valencia (4,470,885 inhabitants). Therefore the limit per party was 504,734.88€ in Extremadura, 135,073€ in La Rioja, 2,279,409.6€ in Catalonia, 431,538.2 € in Murcia, 845,799.6€ in Castilla-León, and $1,028,303.55 €$ in Valencia.

${ }^{10}$ However it is not clear that in Spain is in the interest of incumbents to lower the limit of spending. In the United States, a low ceiling on campaign spending, probably works to the advantage of incumbents because challengers would then have problems to gain name recognition, while the incumbent is well known by voters. But in Spain, electoral competition is among parties not among candidates. Since voters choose among party lists, lowering the ceiling on spending does not benefit incumbents because it would increase competition without letting them reap gains from the lack of name recognition of challengers.
} 
bank loans in order to pay the campaign bill. For the main parties, around 60 per cent of the bill is paid this way.

Other means that parties use to pay for the campaign bill are party funds. It is common for the national organization of parties to contribute to the regional elections. Parties in Spain are very hierarchical and centralized. Transfers from the central organization to the regional ones are common, while transfers among different regional organizations are not. This reinforces the role of the national elites of the parties regarding where to exert a greater campaign effort and which members are to be included in the party list.

The timing of events concerning campaign finance is the following: 1) Parties plan how much to spend in the election; 2) They can request the Public Treasury for a 30\% advance of the subsidy they received in the previous regional election; 3) Campaign bills are paid using bank loans and the 30\% advance of the subsidy; 4) The election takes place; 5) The Public Treasury reimburses parties according to their results; 6) Parties use the public funds to repay bank loans.

Therefore, although campaign funding is public, parties cannot spend as much as they would like because the amount reimbursed by the Public Treasury is subject to limits and depends on their election results. If a party spends more money than their public grant, it has to negotiate directly with the creditors the ways to pay back the debt. In fact all Spanish parties before the nineties were in this situation and even now medium and small parties still suffer from this problem. In such cases, it has been a usual practice in Spanish politics that banks let the debt lie and eventually condone it totally or in part. Therefore bank loans are a sort of corporate contribution and for this reason, an excessive resort to bank loans would put parties at the mercy of their creditors. 


\section{THEORETICAL HYPOTHESES}

In this section we state the theoretical hypotheses to be tested in the paper and provide some rationale for them. We will not propose a formal model from which to derive the hypotheses, but rather the intuition behind them. We intend to motivate the search for the stylized facts on the relationship between campaign spending and the value of office suggested in the next sections.

We assume that party members are office-driven, seeking "to reap the rewards of holding office" (Downs, 1957: 28). Besides other perquisites, office holders can appoint positions like the CEO and other members of the board of directors of publicly owned corporations as well as other government jobs. We also assume that joining a party is the only way to obtain those positions or of being a representative in the regional legislature.

During the election campaign parties maximize the difference between the benefits associated with getting a good result in the election and the costs of campaigning. The utility function of the party is the aggregated utility of its members. The optimum is at the point where marginal benefit equals marginal costs. We adopt the simple model suggested by Abrams and Settle (2004) and consider that, due to office seeking motivations, marginal benefit increases with the size of the public budget, the number of civil servants, and what is most important for our purposes, with the level of political autonomy of the office and the number of positions that can be appointed by the regional executive. With more positions to fill more party members can be rewarded and therefore the greater the marginal benefit from an increase in campaign spending. On the other hand marginal cost shifts with changes in the technology of campaigning and other factors like the risk of corruption scandals if parties resort to illegal campaign contributions. 
Abrams and Settle (2004) and Palda (1992) justify the non-monetary cost of campaigning for candidates in the American political system on the grounds of favors promised to donors in exchange for their funding. In a system where the Treasury finances campaigns, rent-seeking costs of this kind do not work through the same channels ${ }^{11}$. However since campaign expenses are reimbursed after polling day, there is always a risk that parties may spend beyond their means and incur in debt problems that could lead to dependence from the bank lenders or other sources of interested money ${ }^{12}$.

To summarize, at the optimum marginal benefit equals marginal cost for each party. If marginal benefit shifts up when bigger offices or greater selfgovernment powers is the prize to be won, then, in equilibrium, greater marginal costs should be observed in such jurisdictions. Or, in other words, party expenses in the election campaign will be bigger in high-value regions than in low-value ones. As this is the same for all parties, the following related testable implications can be derived from the model just outlined:

H1. Campaign spending increases with the appointment powers of the political office.

H2. Campaign spending increases with the size of the regional government.

\footnotetext{
11 A few rent seeking models built for the American political system consider campaign contributions as a means of buying policy actions. Ansolabehere (2003) presents arguments against this view. In our model lobbying cannot be done in such a fashion due to public funding of campaigns and the strict limit imposed on private contributions.

${ }^{12}$ Evidence from the Court of Accounts' annual reports show that major parties have benefited from the condoning of bank loans on a regular basis. Other sources of interested money (campaign contributions in exchange for political favors) are debts forgiven by companies that provide services to parties during the electoral campaign. Although less used by Spanish parties, the reports of the Court of Accounts show also evidence of this behavior.
} 
H3. Campaign spending increases with the level of autonomy (self-government powers) of the region. The higher the level of autonomy, the greater campaign expenses ceteris paribus.

\section{DATA}

To test the hypotheses stated above we collected data on all the regional elections held in Spain from the mid eighties until 2004. Previous elections were not taken into account due to the lack of accurate data. A total of 86 elections are included: five elections for each of the seventeen Autonomous Communities, except for the region of Andalusia where six observations (including the last election of 2004) were collected ${ }^{13}$.

The following variables are included in our database:

CAMPAIGN: Total campaign expenditures in constant euros. This variable is computed by adding up campaign expenses of all the parties that stood for election in each region.

PERCAPITACAMPAIGN: This variable is computed as CAMPAIGN over ELIGIBLEVOTERS.

PARTYPERCAPITACAMPAIGN: Campaign spending per capita of each of the two major parties in constant euros.

BUDGET: Public budget in constant euros of the region in the year the election was held.

\footnotetext{
${ }^{13}$ The electoral agendas of the 17 Autonomous Communities do not necessarily coincide. Andalusia, Catalonia, Galicia and the Basque Country can choose the date of the election while in the remaining 13 regions it has to be held on the same day that local elections.
} 
PERCAPITABUDGET: BUDGET over ELIGIBLEVOTERS. This variable, a measure of the power to be gained by the winner of the election, is intended to capture the size of the regional government as stated in hypothesis 2 .

GOVWAGES: The total payroll in constant euros of the high level officials appointed by the regional executive in the election year.

PERCAPITAGOVWAGES: GOVWAGES over ELIGIBLEVOTERS. This variable is a proxy for the appointment powers of the regional office as stated in hypothesis 1 . The number of appointed positions over eligible voters would be a better way to capture the appointment powers, but this information was not available for the first regional elections in our database.

ELIGIBLEVOTERS: Number of people entitled to vote in each Autonomous Community in the election year.

PERCAPITAINCOME: Income of the region in millions of constant euros over ELEGIBLEVOTERS.

EXTENSION: Area of the Autonomous Community in square kilometers.

DENSITY: Thousands of eligible voters over square kilometers ${ }^{14}$. It serves as a proxy for the degree of urbanization of the territory. The rationale for this control lies in the fact that the more concentrated the population in a territory, the cheaper for a candidate to campaign as long as more voters can be reached through the typical means of campaigning. This is the reason why less expenditure per voter is to be expected in more populated territories.

${ }^{14}$ (ELIGIBLEVOTERS/1000) /EXTENSION 
COMPETITION: A dummy that takes value 1 if after the election the winner enjoys majority in the regional legislature, otherwise takes value 0 . This variable reflects the degree of political competition in the region. More campaign expenditures are expected in those regions where the result of the election is too close to call. While with first-past-the-post rules the difference in the share of votes between the two candidates is the most widely used measure of competition, for a proportional system we prefer to use a measure that captures whether a party can rule on its own or needs the support of other parties.

HISTDUMMY: A dummy taking value 1 if the Autonomous Community enjoys a high level of autonomy, like Galicia, the Basque Country or Catalonia, and 0 otherwise. It is included to control for those Autonomous Communities with greater policy making powers, and thus is intended to test hypotheses 3.

ELECLAWDUMMY: A dummy taking value 1 if the election was held after the reforms in the voting laws restricted campaign spending in the mid nineties, and 0 otherwise.

LAGVOTESHARE: Vote share of each of the two major parties in the previous election.

Information on campaign expenditures was collected from the financial reports published by the central and regional courts of accounts after each regional election. Data on public budgets came from the budget departments of the regional governments. Information on the payroll of appointed high-level officials derives from the same source, except for the Autonomous Community of Valencia, where the civil servant in charge of providing the information refused to collaborate. For this reason, the payroll of high-level officials for the 1987 and 1991 elections in the region of Valencia are missing in our database. We obtained the data for the next three elections in this region from its annual 
budgets. Information on the election results was collected from the websites of each of the Autonomous Assemblies. Data on the region's eligible voters, income and square kilometers was gathered from the Spanish Statistical Institute (INE). All the monetary variables are in constant 1992 euros. The Consumer Price Index (IPC) computed by the INE was used to convert the monetary variables into constant euros.

\section{METHODS}

Summary statistics of data, presented it table 1 , show that there is enough cross sectional variation in the sample to justify the use of panel data methods. This is reflected by the fact that between standard deviation is consistently higher than within standard deviation.

In order to test hypotheses 1 to 3 , we assume a linear relationship and propose the following model:

$$
Y_{i t}=a+b X_{i t}+c Z_{i t}+\varepsilon_{i t}
$$

Where $Y_{i t}$ is the dependent variable that measures campaign expenditures per capita; $X_{\mathrm{it}}$ is the set of independent variables that capture the value of government for the parties standing for election (i.e., PERCAPITAGOVWAGES, PERCAPITABUDGET, and HISTDUMMY); $Z_{i t}$ is the vector of control variables; $a, b$ and $c$ are vectors of parameters to be estimated, and $\varepsilon_{i t}$ is the disturbance.

Positive coefficients of the $X_{i t}$ variables would support our hypotheses that campaign expenditures increase with the size of office and the appointment 
powers of the regional executive. Negative values of the coefficients would contradict our claims.

To take advantage of the panel structure of our database we first compared the pooled OLS results with the GLS random effects estimates (RE) and with the estimates of a fixed effects model (LSDV) by Autonomous Communities. Breusch and Pagan's (1980) Lagrange multiplier test for random effects was carried out showing values greater than the relevant chi-square critical point, so the null hypotheses that corr. $\left(\varepsilon_{i t}, \varepsilon_{i s}\right)=0$, where $\varepsilon_{i t}=v_{i}+u_{i t}$, was rejected and we concluded that the random effects model may be a better specification than the pooled OLS for our data. Then we compared RE estimates with fixed effects. The random effects specification requires the errors to be uncorrelated with other regressors in the model; otherwise the LSDV approach would be more appropriate. Hausman's specification test for fixed and random effects showed values smaller than the chi-square critical point. Thus, the test suggests that the RE model is more suitable for our data.

However, both Wald's test for heteroscedasticity ${ }^{15}$ and Woolridge's (2002: 28284) test for autocorrelation detected the presence of heteroscedasticity across panels and autocorrelation within panels. Beck and Katz (1995) showed that in that case and when the number of cross-sectional units is greater than the number of time periods (N>T), FGLS estimates of the standard errors are biased downwards ${ }^{16}$. Since in our database, $N=17$ and $T=5$, we followed their advice

15 See Green (2003: 323).

16 The Feasible Generalized Least Squares variance estimate is obtained from:

$$
\begin{aligned}
& E s t . V a r\left(\beta_{F G L S}\right)=\left(X^{\prime} \hat{\Omega} X\right)^{-1} X^{\prime} \hat{\Omega}^{-1} y \\
& \hat{\Omega}_{i, j}=\frac{e_{i} e_{j}}{T}
\end{aligned}
$$

Where the residuals $\mathrm{e}_{i}$ are computed by OLS. The estimated $\Omega$ matrix is at most of rank min $(\mathrm{T}$, N) if panels are correlated as is our case. Beck et al. (1993) showed that we cannot use this 
and finally used Panel Corrected Standard Errors (PCSE) in order to obtain robust results ${ }^{17}$. To account for serial correlation of residuals within panels we assumed a simple AR (1) autoregressive process and estimated the equations using the Prais-Winsten transformed regression estimator ${ }^{18}$. An alternative that leads to very similar results is to estimate the pooled model clustering the standard errors by region. The results from this alternative method lead to the same conclusions reported below and are available upon request from the authors.

Finally, to account for a possible endogeneity problem in our specification we also estimated the model using Baltagi's $(1980,1995)$ EC2SLS estimator ${ }^{19}$. The source of the potential endogeneity problem comes from the fact that in the medium run the number of appointed positions for high-level officials depends on decisions taken by the party governing the region.

Table 2 offers the estimated coefficients of the different models. Columns 1 to 3 show the Panel Corrected Standard Errors results, column 4 the results of the model estimated by party and column 5 the parameters of the Random Effects 2SLS model. We now move to the discussion of these results.

variance unless $\mathrm{T}$ is at least as large as $\mathrm{N}$. In our case since $\mathrm{T}(=5)$ is smaller than $\mathrm{N}(=17)$, FGLS is not appropriate. See Beck et al. (1993) and Beck and Katz (1995) for details.

17 The estimated variance in the PCSE model is given by:

$\operatorname{Var}\left(\beta_{\text {PCSE }}\right)=\left(X^{\prime} X\right)^{-1} X^{\prime} \hat{\Omega} X\left(X^{\prime} X\right)^{-1}$

$\hat{\Omega}=\frac{e_{i} e_{j}}{T_{i, j}}$

Where $e_{i}$ and $e_{j}$ are the residuals of panel $i$ and panel $j$ and Tij is the number of residuals between the panels that that can be matched by period.

${ }^{18}$ The Prais-Winsten estimator is computed running OLS after multiplying the observations corresponding to the first period by $\left(1-\rho^{2}\right)^{1 / 2}$ and transforming the others by $\mathrm{y}_{\mathrm{t}}{ }^{*}=\mathrm{y}_{\mathrm{t}}-\rho \mathrm{y}_{\mathrm{t}-1}$ and $\mathrm{x}_{\mathrm{t}}{ }^{*}=\mathrm{x}_{\mathrm{t}}-\rho \mathrm{x}_{\mathrm{t}-1}$, where $\rho$ is the estimated serial correlation coefficient.

19 This estimator is a weighted combination of the between groups 2SLS, the between timeperiods 2SLS and the within 2SLS. Baltagi (1984) offers Monte Carlo evidence showing the better performance of this estimator in small samples of panel data compared to the usual 2SLS. See Baltagi (1984) for details. 


\section{RESULTS}

We start discussing the Panel Corrected Standard Errors results of regressions 1 to 3 in table 2. In all of them the dependent variable is campaign expenditure per capita. In regression 1 we use as a measure of the appointment power the payroll of appointed high officials per capita. In regression 2 we use budget per capita and in regression 3 we include both of them. In order to control for other factors influencing campaign expenses we include in the regression equations the DENSITY variable as a proxy for urbanization and PERCAPITAINCOME to account for region's income differences. We also include dummies to capture the impact of the legal reforms of campaign spending in the nineties and the greater political powers of some of the regions. The results support our hypotheses 1 since the coefficient for the variable measuring the value of political power is positive, as expected, and significant in all the specifications. According to regression 1 and 3, an increase of one euro in the payroll of appointed high-level officials per capita leads to an increase of 0.09 euros in campaign spending per capita. This result is significant at the $99 \%$ level.

In addition, in all the equations the dummy that measures the level of political autonomy (HISTDUMMY) has a positive and significant sign, giving support to the hypothesis that with more self-government powers greater campaign expenses are to be expected. In fact, the coefficients reflect that approximately 0.8 euros more per capita are to be anticipated in regions with expanded policymaking capacities.

The signs of the remaining control variables match the expected ones. In those regions where voters are geographically concentrated electoral costs are lower, as reflected by the negative sign of the DENSITY parameter. In addition, electoral costs per eligible voter diminished after legal limits were imposed on 
campaigning in the nineties. Regressions 1 to 3 show also that COMPETITION exerts an independent influence on campaign expenditures per capita. The level of political competition is negative and significant in all the models indicating that less campaign spending is to be expected in those elections where there is a clear winner. Finally, the positive sign of the variable that measures income per capita reflects that campaign spending seems to be a normal good.

It is somewhat surprising however, that the other variable that measures the power of the region, PERCAPITABUDGET is not significant in any of these specifications (see regression 2 and 3$)^{20}$. In previous studies for the U.S. system i.e., Palda (1992: 631) - this variable is the preferred measure of power. A plausible explanation is that this result is a consequence of the Spanish political system in which private contributions play a negligible role on campaign spending and where party elites are the main political actors. The positive and significant sign of the coefficient estimates of PERCAPITAGOVWAGES reflect the interest of party elites on increasing the utility of party members by nominating them for government positions. Previous studies have argued that the size of the public budget captures how much interest groups value power. In the Abrams and Settle papers of the seventies as well as in Palda (1992) or Lott (2000), budget per capita is the most relevant variable. This makes sense for American politics because campaign contributions can be assumed to reflect how much donors assess a political office. For contributors, the size of the public budget is an obvious measure of how much power the candidate is going to have. In Spanish politics where contributors play a modest role and appointed positions are usually offered to party members, the number of such jobs or the payroll for appointed high level officials reflect more accurately the nominating power of the regional government and therefore its value for the party.

\footnotetext{
${ }^{20}$ Using budget as a percentage of the region's income leads also to non-significant estimates. The results for this regression are available upon request.
} 
Another related explanation for the non-significant estimate of the size of PERCAPITABUDGET could be that using aggregated campaign spending of all parties in each region as the dependant variable may hide the influence of the size of the public sector as a measure of power for some parties because it includes campaign spending of small and medium sized parties for which their main interest is to obtain a certain number of seats in the assembly or a few government positions through government coalitions but whose value for interest groups trying to purchase policies is small.

This explanation is consistent with the results of regression 4 in which we have used disaggregated data on campaign spending for the two main Spanish parties, PP and $\mathrm{PSOE}^{21}$. We have also included as an additional regressor the vote share of each party in the previous election to account for the different weight of each party in each territory. The estimate of PERCAPITABUDGET is now positive and significant although only at the $90 \%$ level $^{22}$.

Another complementary factor that may be responsible for the low significance of the estimate of the coefficient of budget per capita in this model or the nonsignificance in the previous ones is the asymmetrical federalism of Spain. Different regions have undertaken different political tasks over time. When a region takes a task that was previously in the hands of the central government, it also obtains extra funding for it. Sometimes however, the resources transferred by the central government are insufficient. Therefore, a bigger public sector is not always beneficial for the party in charge of a region if the new liabilities are underfunded. This was the case in Spain in the late nineties when expenditures in Education and Health were decentralized. The funds

\footnotetext{
${ }^{21}$ We estimate this model using pooled OLS clustering standard errors by region.

${ }^{22}$ The coefficients of regression 4 are not directly comparable to those obtained in regressions 1 to 3 because the dependent variable is different (much smaller because it includes just the party specific campaign spending instead of the overall campaign spending).
} 
received by regions were clearly insufficient during the first years and had to be updated later on. PERCAPITABUDGET may be therefore in this case a noisy indicator of the value of a political office.

Finally, we show in regression 5 of table 2 an additional test of the robustness of our preferred measure of power, PERCAPITAGOVWAGES, allowing for possible endogeneity between campaign expenditures and government positions. We use as instruments for PERCAPITAGOVWAGES the number of eligible voters as well as all other exogenous variables in the model ${ }^{23}$. The results show again that the appointment power of the regional executive has a significant and positive effect on campaign expenditures per capita. The HISTDUMMY and ELECLAW variables as well as COMPETITION and PERCAPITAINCOME have also the expected signs and significant t-statistics.

To sum up, our results show that campaign expenditures are consistently higher in per capita terms in those jurisdictions where there are more government positions to distribute among party members (high-value regions). This result is robust to the presence of heteroscedasticity, autocorrelation and endogeneity problems. Moreover, in those regions with a greater level of autonomy campaign expenditures per capita are also higher. In addition, budget per capita seems to increase with campaign expenses per capita although the size of the effect is uncertain as reflected in low $\mathrm{t}$-values.

A few words of caution should be put to close this section. First, our small sample of 86 observations, although larger than some of the previous studies mentioned above, makes us cautious about the asymptotic validity of the estimates obtained here. Second, the appointment powers of the regional

23 A simple regression of the dependent variable on VOTERS yielded non-significant coefficients of this variable. In addition a regression of the instrumented variable on VOTERS yielded significant t-statistics as well as an F value greater than 10 . 
executives should be better measured by the number of government positions to be filled and better controlled by the number of affiliates of each party. This information is not yet available in Spain from reliable sources. Third, policyseeking motivations have been excluded from the study in order to highlight the influence of the value of office as an asset for the governing party. A more complete model of the combined effects of office and policy seeking motivations is left for future work.

\section{CONCLUDING REMARKS}

We have provided econometric evidence suggesting that office-seeking motivations, as measured by the payroll for appointed high-level officials, public budgets or law making capacities, affect campaign spending. Our data are from Spain, a country where campaign expenses are publicly financed for major parties and plurality rules determine the composition of regional legislatures.

Several facts make this result interesting. First, there is a scarcity, as far as we know, of evidence about the effects of office seeking motivations on campaign expenditures for countries other than the U.S. Second, surprisingly enough, our results concord with those obtained for the U.S. in other research studies. They confirm that even with different voting and campaign financing rules the power to be gained by the candidates for an office is a relevant influence on campaign spending. Third, in the case presented here campaign expenses are more affected by party elites than by interest groups trying to purchase policies.

Last, the line of research presented here could be extended in the future in several directions. First, the role of policy seeking motivations should be analyzed and included into the determinants of campaign spending. Second, 
other measures of political power, such as the number of civil servants or high level officials that can be appointed by the governing party, could reflect more accurately the prize parties are competing for. And third, similar studies for other countries with party discipline, public campaign financing and plurality rules should be carried out so that a better understanding of the interaction of campaign expenditures, political power and voters' behavior could be attained.

\section{REFERENCES}

Abrams, B. A. (1981): "Political Power and the Market for Governors", Public Choice, 37, 521-529.

Abrams, B. A.; Settle, R. F. (1976): "The Effect of Broadcasting on Political Campaign Spending", Journal of Political Economy 84, 1095-1107.

Abrams, B. A.; Settle, R. F. (2004): “Campaign-Finance Reform: A Public Choice Perspective", Public Choice 120, 379-400.

Ansolabehere, S.; De Figueiredo, J.; Snyder, J.M. (2003): “Why Is There So Little Money in U.S. Politics?", Journal of Economic Perspectives, 17 , 105-130.

Artés Caselles, J.; García Viñuela, E. (2005): "Reforming Electoral Finance in the Nineties: A Case Study of Spain" (May 12, 2005). Center for the Study of Democracy.Working Paper G05-01.

Artés Caselles, J.; García Viñuela, E. (2006): “Economía Política de las Reformas de la Financiación Electoral", Revista Española de Ciencia Política, 15. 
Baltagi, B. H. (1984): “A Monte Carlo Study for Pooling Time Series of CrossSection Data in the Simultaneous Equations Model", International Economic Review, 25, 603-624.

Baltagi, B. H. (1995): Econometric Analysis of Panel Data, New York: John Willey and Sons.

Beck, N.; Katz, J. N. (1995): “What To Do (and Not To Do) with Time-Series Cross-Section Data", American Political Science Review, 89, 634 -647.

Beck, N.; Katz, J.N.; Alvarez, M.; Garret, G.; Lange, P. (1993): “Government Partisanship, Labor Organization, and Macroeconomic Performance: A Corrigendum", American Political Science Review, 87, 945-948.

Breusch, T.; Pagan, A. (1980): “The LM Test and its Applications to Model Specification in Econometrics", Review of Economic Studies, 47, 239-254.

Bronnars, S.; Lott J. Jr. (1997): “Do Campaign Contributions Alter How Politicians Votes? Or Do Donors Support Candidates Who Value the Same Things That they Do?", Journal of Law and Economics, 40, 317-350.

Crain, W. M.; Tollison, D (1977). “Attenuated Property Rights and the Market for Governors", Journal of Law and Economics, April, 205-211.

Crain, W. M.; Deaton, T., Tollison, D. (1977): “Legislators as Taxicabs: On the Value of Seats in the U.S. House of Representatives", Economic Inquiry, April, 298-302.

Downs, A. (1957): An Economic Theory of Democracy, New York: Harper \& Row. 
Gifford, A.; Santoni, G. J. (1978): “Politicians and Property Rights: An Analysis of the Relationship Between Campaign Expenditures and Wage and Price Controls", Public Choice 33, 71-74.

Green, W. H. (2003): Econometric Analysis, Upper Saddle River, New Jersey: Prentice Hall.

Lott, J. Jr, (2000): “A Simple Explanation Why Campaign Expenditures Are Increasing: The Government is Getting Bigger", Journal of Law and Economics, 43, 359-393.

Palda, F. (1992): “The Determinants of Campaign Spending: The Role of the Government Jackpot", Economic Inquiry, 30, 627-638.

Settle, R.F. and Abrams, B.A. (1976): “The Determinants of Voter Participation: A More General Model", Public Choice 27, 81-89.

Stratmann, T. (1991): “What Do Campaign Contributions Buy?: Deciphering Causal Effects of Money and Votes", Southern Economic Journal, 57, 606-620.

Woolridge, J.M. (2002): Econometric Analysis of Cross Section and Panel Data, Cambridge, Cambridge University Press. 
Table 1. Summary Statistics

Mean Std Dev. Min. Max. Observations.

PERCAPITACAMPAIGN

\begin{tabular}{|c|c|c|c|c|c|}
\hline Overall & 1.083228 & 0.5781 & 0.163495 & 3.4617 & $\mathrm{~N}=86$ \\
\hline Between & & 0.5127 & & & $\mathrm{n}=17$ \\
\hline Within & & 0.2947 & & & $\mathrm{~T}-\mathrm{bar}=5.06$ \\
\hline
\end{tabular}

PERCAPITAGOVWAGES

\begin{tabular}{|c|c|c|c|c|c|}
\hline Overall & 2.5923 & 1.5031 & 0.478 & 6.658 & $\mathrm{~N}=84$ \\
\hline Between & & 1.369 & & & $\mathrm{n}=17$ \\
\hline Within & & 0.6754 & & & $\mathrm{~T}$-bar $=4.94$ \\
\hline
\end{tabular}

PERCAPITABUDGET

\begin{tabular}{|c|c|c|c|}
\hline Overall & 1351.645 & $815.5605 \quad 248.0958 \quad 3539.713$ & $\mathrm{~N}=86$ \\
\hline Between & & 532.1208 & $\mathrm{n}=17$ \\
\hline Within & & 629.6771 & $\mathrm{~T}-\mathrm{bar}=5.06$ \\
\hline
\end{tabular}

VOTERS

\begin{tabular}{|c|c|c|c|c|}
\hline Overall & 1906261 & $1635201 \quad 201737$ & 6052012 & $\mathrm{~N}=86$ \\
\hline Between & & 1625085 & & $\mathrm{n}=17$ \\
\hline Within & & 187390.6 & & $\mathrm{~T}-\mathrm{bar}=5.06$ \\
\hline
\end{tabular}

PERCAPITAINCOME

\begin{tabular}{|c|c|c|c|c|c|}
\hline Overall & 0.012 & 0.0029 & 0.007 & 0.02 & $\mathrm{~N}=86$ \\
\hline Between & & 0.0026 & & & $\mathrm{n}=17$ \\
\hline Within & & 0.0015 & & & $\mathrm{~T}-\mathrm{bar}=5.06$ \\
\hline
\end{tabular}

EXTENSION

\begin{tabular}{|c|c|c|c|c|c|}
\hline Overall & 30360.67 & 30156.65 & 5014 & 94193 & $\mathrm{~N}=86$ \\
\hline Between & & 30418.84 & & & $\mathrm{n}=17$ \\
\hline Within & & 0 & & & $\mathrm{~T}$-bar $=5.06$ \\
\hline
\end{tabular}

DENSITY

\begin{tabular}{|c|c|c|c|c|c|}
\hline Overall & 0.1099 & 0.1165 & 0.0145 & 0.5557 & $\mathrm{~N}=86$ \\
\hline Between & & 0.1193 & & & $\mathrm{n}=17$ \\
\hline Within & & 0.1274 & & & $\mathrm{~T}-\mathrm{bar}=5.06$ \\
\hline
\end{tabular}


Table 2. Regressions of Campaign Expenditures per voter

\begin{tabular}{|c|c|c|c|c|c|}
\hline \multirow[t]{2}{*}{ Regressors } & \multicolumn{3}{|c|}{ PCSE } & \multirow{2}{*}{\begin{tabular}{|c|}
$\begin{array}{c}\text { By party } \\
\text { spending. } \\
\text { Clustered SE }\end{array}$ \\
4
\end{tabular}} & \multirow{2}{*}{$\begin{array}{c}\text { EC2SLS } \\
5 \\
\end{array}$} \\
\hline & 1 & 2 & 3 & & \\
\hline PERCAPITAGOVWAGES & $\begin{array}{l}0.09^{* \star *} \\
(0.03)\end{array}$ & & $\begin{array}{l}0.09^{* * *} \\
(0.03)\end{array}$ & $\begin{array}{l}0.03^{\star \star *} \\
(0.01)\end{array}$ & $\begin{array}{l}0.07^{*} \\
(0.04)\end{array}$ \\
\hline PERCAPITABUDGET & & $\begin{array}{c}0.00002 \\
(0.00006)\end{array}$ & $\begin{array}{c}-0.06 \mathrm{E}-4 \\
(0.00007)\end{array}$ & $\begin{array}{l}0.000003^{*} \\
(0.000017)\end{array}$ & \\
\hline HISTDUMMY & $\begin{array}{c}0.79^{\star \star *} \\
(0.18)\end{array}$ & $\begin{array}{c}0.87^{\star \star \star} \\
(0.21)\end{array}$ & $\begin{array}{l}0.79^{\star \star \star} \\
(0.19)\end{array}$ & $\begin{array}{c}0.23^{\star \star \star} \\
(0.02)\end{array}$ & $\begin{array}{l}0.95^{\star \star \star} \\
(0.10)\end{array}$ \\
\hline COMPETITION & $\begin{array}{l}-0.18^{\star} \\
(0.10)\end{array}$ & $\begin{array}{l}-0.20^{\star} \\
(0.09)\end{array}$ & $\begin{array}{l}-0.19^{*} \\
(0.09)\end{array}$ & $\begin{array}{c}-0.04^{\star *} \\
(0.02)\end{array}$ & $\begin{array}{c}-0.26 * \star \star \\
(0.07)\end{array}$ \\
\hline DENSITY & $\begin{array}{c}-0.62^{\star \star} \\
(0.32)\end{array}$ & $\begin{array}{c}-1.05^{\star \star \star} \\
(0.23)\end{array}$ & $\begin{array}{c}-0.66^{\star \star} \\
(0.31)\end{array}$ & $\begin{array}{c}-0.28^{\star \star \star} \\
(0.08)\end{array}$ & $\begin{array}{c}-1.18^{\star \star \star} \\
(0.40)\end{array}$ \\
\hline ELECTLAWDUMMY & $\begin{array}{c}-0.27^{\star \star \star} \\
(0.09)\end{array}$ & $\begin{array}{l}-0.24^{\star} \\
(0.14)\end{array}$ & $\begin{array}{c}-0.27^{\star \star} \\
(0.12)\end{array}$ & $\begin{array}{c}-0.05^{\star \star} \\
(0.02)\end{array}$ & $\begin{array}{c}-0.31^{\star \star \star} \\
(0.08)\end{array}$ \\
\hline PERCAPITAINCOME & $\begin{array}{l}0.03^{*} \\
(0.02)\end{array}$ & $\begin{array}{l}0.05^{\star \star \star} \\
(0.02)\end{array}$ & $\begin{array}{l}0.03^{*} \\
(0.02)\end{array}$ & $\begin{array}{c}0.005 \\
(0.005)\end{array}$ & $\begin{array}{c}0.06^{\star \star \star} \\
(0.02)\end{array}$ \\
\hline LAGVOTESHARE & & & & $\begin{array}{l}0.37^{\star \star \star} \\
(0.05)\end{array}$ & \\
\hline Constant & $\begin{array}{c}0.65^{\star \star \star} \\
(0.18)\end{array}$ & $\begin{array}{l}0.64^{\star \star \star} \\
(0.20)\end{array}$ & $\begin{array}{c}0.63^{\star \star \star} \\
(0.16)\end{array}$ & $\begin{array}{c}-0.004 \\
(0.1357)\end{array}$ & $\begin{array}{c}0.95^{\star \star \star} \\
(0.1759)\end{array}$ \\
\hline $\begin{array}{c}\text { R-sq } \\
\mathrm{N} \\
\text { Wald-test (prob>chi2) }\end{array}$ & $\begin{array}{c}0.52 \\
84 \\
702.57(0.00) \\
\end{array}$ & $\begin{array}{c}0.49 \\
86 \\
69.97(0.00)\end{array}$ & $\begin{array}{c}0.53 \\
84 \\
922.91(0.00)\end{array}$ & $\begin{array}{c}0.59 \\
168 \\
40.99(0.00) \\
\end{array}$ & $\begin{array}{c}0.60 \\
84 \\
179.93(0.00) \\
\end{array}$ \\
\hline
\end{tabular}

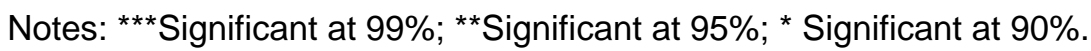

The dependent variable in regressions $1,2,3$ and 5 is PERCAPITACAMPAIGN.

The dependent variable in regression 4 is PARTYPERCAPITACAMPAIGN

Standard errors are in parentheses.

The instrument in regression 5 is VOTERS and all the other exogenous variables in regression 1 